\title{
PENENTUAN JUMLAH KOLONI BAKTERI PADA TAHU PUTIH YANG DIJUAL DIPASAR BARU KECAMATAN ARUT SELATAN
}

\author{
Agustoni Pujianto ${ }^{1}$ Febry Nur Ngazizah ${ }^{2}$ \\ ${ }^{12}$ STIKes Borneo Cendekia Medika Pangkalan Bun \\ ${ }^{1}$ Email : AgustoniPujianto@gmail.com
}

\begin{abstract}
ABSTRAK
Telah dilakukan penelitian penentuan jumlah koloni bakteri pada Tahu putih yang dijual di Pasar Baru Kecamatan Arut Selatan. Penelitian ini bertujuan untuk menentukan jumlah koloni bakteri pada tahu putih. Pada penelitian ini menggunakan perhitungan jumlah koloni bakteri dengan cara tidak langsung dengan menggunakan metode Total Plate Count. Hasil penelitian menunjukan bahwa Tahu putih pada sampel pagi (I) $1.210 \times 10^{6}=1.210 .000 .00 \mathrm{koloni} / \mathrm{ml}$, sampel siang (II) 1.380 $\mathrm{x} 10^{6}=1.380 .000 .00 \mathrm{koloni} / \mathrm{ml}$, sampel sore (III) $2.14 \mathrm{x} 10^{6}=2.140 .000 .00$ koloni/ml. Syarat perhitungan jumlah koloni antara 30 sampai 300 koloni bakteri. Berdasarkan persyaratan jumlah koloni bakteri sudah ditetapkan balai POM yaitu bakteri maksimal adalah $10^{4}$. Dari ketiga sampel Tahu putih putih tersebut menyatakan jumlah koloni yang paling banyak yaitu pada sampel III sebesar 2.140.000.00 koloni/ml.
\end{abstract}

Kata kunci : Bakteri, Tahu putih, Total Plate Count.

\section{DETERMINATION OF THE NUMBER OF BACTERIAL COLONIES ON WHITE KNOWS FOR SALE IN THE NEW MARKET DISTRICT, SOUTH ARUT}

\begin{abstract}
A study was conducted to determine the number of bacterial colonies in white tofu sold in Pasar Baru, South Arut District. This study aims to determine the number of bacterial colonies in white tofu. In this study using the calculation of the number of bacterial colonies indirectly by using the Total Plate Count method. The results showed that white tofu in the morning sample (I) $1,210 \times 10^{\wedge} 6=1,210,000.00$ colonies / $\mathrm{ml}$, afternoon samples (II) $1,380 \times 10 \wedge 6=1,380,000.00$ colonies / $\mathrm{ml}$, afternoon samples (III) $2.14 \times 10^{\wedge} 6=2,140,000.00$ colonies / ml. Requirements for calculating the number of colonies between 30 to 300 bacterial colonies. Based on the requirements for the number of bacterial colonies, the POM center has been determined, namely a maximum bacterium of $10^{\wedge} 4$ Of the three samples of white and white tofu stated that the highest number of colonies was in sample III of 2,140,000.00 colonies / $\mathrm{ml}$.
\end{abstract}

Keywords: Bacteria, White Tofu, Total Plate Count. 


\section{PENDAHULUAN}

Indonesia sebagai Negara berkembang dalam pemenuhan kebutuhan gizi penduduknya masih mendapat kendala, yang tampak dari adanya beberapa daerah yang tak tercukupkan bahan pangan terutama jika musim kemarau tiba. Hal ini mengakibatkan timbulnya penyakit defesiensi gizi, yang jika berkelanjutan bisa berakibat lebih parah terutama pada anak-anak dalam masa pertumbuhannya. Untuk itu makanan yang kita konsumsi sehari-hari seharusnya memenuhi standar gizi yang dibutuhkan untuk menghasilkan kalori sehingga dapat melakukan aktifitas (Buckle, et.al, 1985).

Protein merupakan zat gizi penting di samping lemak dan karbohidrat yang berfungsi terutama sebagai zat pengatur pergerakan, pertahanan tubuh, alat pengangkut dalam jaringan tubuh serta beberapa fungsi sampingannya. Kebutuhan akan protein semakin meningkat terutama dalam kondisi ibu mengandung, menyusui serta masa-masa pertumbuhan anak (Winarto,1997).

Salah satu sumber makanan dengan kandungan protein yang cukup tinggi, harga murah dan mudah diperoleh adalah tahu. Tahu merupakan penyumbang terbesar dalam pemenuhan kebutuhan gizi protein nabati masyarakat. Karena itu adanya produk tahu yang bermutu rendah sangat merugikan masyarakat, apalagi dalam taraf tertentu dapat membahayakan konsumen. Kontaminasi mikroorganisme baik berupa bakteri maupun jamur tersebut kemungkinan kurangnya hygine baik bahan baku, peralatan, maupun pembuatan tahu itu sendiri. Tahu putih yang kurang bersih dapat mengganggu kesehatan seperti penyakit diare, yang disebabkan oleh Vibrio cholera, Esscherichia coli, ataupun penyakit infeksi lainnya. Oleh karena itu perlu dilakukan pengujian terhadap keberadaan mikroorganisme dengan melihat jumlah koloni bakteri.

\section{METODE PENELITIAN}

\section{Alat Penelitian}

Alat yang digunakan dalam penelitian ini antara lain: batang pengaduk, beaker glass, cawan petri, enkas, erlenmeyer, oven, hot plate, inkubator (Memmert), mikro pipet, magnetik stirer, neraca analitik, ose, otoklaf, pembakaran spiritus, pipet volume, rak tabung reaksi dan tabung reaksi.

2. Bahan Penelitian

Adapun bahan-bahan yang digunakan dalam penelitian ini antara lain: alkohol, aquades steril, tahu putih, kertas sampul, medium Nutrien Agar (NA), $\mathrm{NaCl}$ fisiologis, spiritus.

\section{Lokasi Penelitian}

Penelitian tentang jumlah bakteri pada tahu putih yang di ambil di Pasar Baru, Kecamatan Arut Selatan, Kabupaten Kotawaringin Barat, Pangkalan Bun, pengujian dilakukan di Sekolah Tinggi Kesehatan Borneo Cendekia Medika Pangkalan Bun

\section{Prosedur Kerja}

$$
\text { Sampel }
$$
tahu digerus/dihaluskan ditimbang sebanyak 1gdimasukan kedalam tabung reaksi yang sudah berisi $\mathrm{NaCl10ml}$ dibuat pengenceran $10^{-1}, 10^{-2}, 10^{-3}$, $10^{-4}, 10^{-5}$ hasil pengenceran $10^{-3}, 10^{-4}, 10^{-5}$ dipipet sebanyak $1 \mathrm{ml}$ dimasukan kedalam cawan petri, ditambahkan medium NA. Setelah itu diinkubasi pada suhu 
$37^{\circ} \mathrm{C}$ selama $24-48$ jam dihitung hasil pengamatan jumlah koloni.

\section{a. Pengambilan Sampel}

Sampel berupa tahu putih diambil di Pasar Baru dari Penjual yang berbeda dan berdasarkan waktu/lama penyimpanan, yaitu yang dijual pagi hari dan dijual disore hari.

b. Penyiapan Sampel Uji

Tahu putih disiapkan kemudian ditumbuk/digerus di dalam lumpang sampai lembut, ditimbang sebanyak 1 g kemudian dimasukan kedalam tabung reaksi yang berisi $\mathrm{NaCl}$ 10ml. Dilakukan pengenceran dari $10^{-1}$ sampai $10^{-5}$, setelah pengenceran dilakukan uji dengan metode lempeng agar.

\section{c. Sterilisasi Alat}

Alat yang akan
digunakan dicuci dengan
deterjen lalu dibilas dengan air
aquades, kemudian alat berupa
cawan petri, batang pengaduk,
mikro pipet, pipet volum dan
tabung reaksi dibungkus
dengan kertas sampul dan
disterilkan dalam oven pada
suhu $121^{0} \mathrm{C}$ tekanan 2 atm
(atmosfir) selama 15 menit.
Ose disterilkan dengan cara
dipijarkan pada nyala api
spiritus.

d. Pembuatan dan Sterilisasi Medium

Sebanyak 5,75 gram medium Nutrien Agar ( NA ) instan dilarutkan dalam aquades $300 \mathrm{ml}$ air suling steril, diaduk sampai larut dan disaring menggunakan kain saring yang bersih. Kemudian disterilkan dengan menggunakan otoklaf pada suhu $121^{\circ} \mathrm{C}$ pada tekanan 2 atm (atmosfir) selama 15 menit.

\section{Pengujian Jumlah Bakteri}

Menggunakan medium NA bahan pengencernya $\mathrm{NaCl}$ fisiologis. Dengan cara aseptis dipipet $1 \mathrm{ml}$ sampel tahu putih kedalam tabung reaksi steril ditambahkan dengan $9 \mathrm{ml} \mathrm{NaCl}$ fisiologis, dihomogenkan selama 30 detik sehingga terbentuk suspensi homogen dengan pengenceran $\quad 10^{-1}$.Kemudian disiapkan 5 buah tabung reaksi dengan masing-masing sudah berisi $9 \mathrm{ml} \mathrm{NaCl}$ fisiologis. Dipipet $1 \mathrm{ml}$ suspensi $10^{-1}$ kedalam tabung yang berisi $9 \mathrm{ml}$ pengencer $\mathrm{NaCl}$ fisiologis dikocok sampai diperoleh suspensi dengan pengenceran $10^{-2}$. Pengenceran berikutnya dilanjutkan hingga terbentuk suspensi akhir dengan pengenceran $10^{-5}$ untuk sampel I sedangkan untuk sampel yang ke II dan ke III pengenceran dilakukan dengan metode yang sama. Setiap cawan petri dituang $10 \mathrm{ml}$ medium NA, suspensi bakteri pada masing-masing pengencer dipipet sebanyak $1 \mathrm{ml}$ dimasukan kedalam medium dan digoyang sambil diputar hingga suspensi merata, kemudian cawan petri di inkubasi pada suhu $35^{\circ}-37^{\circ} \mathrm{C}$ selama 2448 jam dalam posisi terbalik. Jumlah koloni yang tumbuh diamati dan dihitung jumlah koloni bakterinya, untuk bakteri syaratnya tidak lebih dari $10^{4}$ koloni per $\mathrm{ml}$.

\section{HASIL DAN PEMBAHASAN}

Dari hasil pengamatan penelitian sifat koloni bakteri yang masuk dalam hitungan penelitian yang sifat koloni yang muncul berupa 
kumparan, permukaan, permukaaan koloni datar, tidak berbukit dan tepi koloni ada yang utuh, ada juga yang berombak maka diperoleh data koloni bakteri sebagai berikut :

Tabel 1 Hasil pengamatan jumlah koloni bakteri pada Tahu putih dengan menggunakan medium NA (Nutrien Agar).

\begin{tabular}{|c|c|c|c|c|}
\hline \multirow{2}{*}{$\begin{array}{c}\text { samp } \\
\text { el }\end{array}$} & \multicolumn{3}{|c|}{$\begin{array}{c}\text { Pengenceran } \\
\text { diinkubasi selama 24 } \\
\text { jam }\end{array}$} & \multirow{2}{*}{ Hasil } \\
\cline { 2 - 4 } & $10^{-3}$ & $10^{-4}$ & $10^{-5}$ & \\
\hline $\begin{array}{c}\text { (I)Pa } \\
\text { gi }\end{array}$ & 337 & 121 & 97 & $\begin{array}{c}121 \mathrm{x} \\
10^{6}\end{array}$ \\
\hline $\begin{array}{c}\text { (II)Si } \\
\text { ang }\end{array}$ & 364 & 138 & 112 & $\begin{array}{c}138 \mathrm{x} \\
10^{6}\end{array}$ \\
\hline $\begin{array}{c}\text { (III)S } \\
\text { ore }\end{array}$ & 389 & 237 & 191 & $\begin{array}{c}2,14 \mathrm{x} \\
10^{6}\end{array}$ \\
\hline
\end{tabular}

Sumber : Data primer, 2013.

Dari tabel diatas dapat diketahui bahwa pada sampel I, II, III pertumbuhan koloninya diantara 30300. Hal ini memenuhi persyaratan untuk perhitungan koloni. Dari tabel diatas dapat disimpulkan bahwa :

1. Pada sampel (I) Pagi, jumlah koloni yang tumbuh $121 \times 10^{6}$

2. Pada sampel (II) Siang, jumlah koloni yang tumbuh $138 \times 10^{6}$

3. Pada sampel (III) Sore, jumlah koloni yang tumbuh $2.14 \times 10^{6}$

Dari hasil perhitungan jumlah koloni diatas dapat disimpulkan bahwa sampel Tahu putih yang dijual pada sore hari lebih banyak terdapat jumlah bakterinya dari pada sampel Tahu putih yang dijual pada pagi hari dan siang hari.

Adapaun beberapa faktor yang dapat menyebabkan adanya cemaran bakteri pada sampel Tahu putih antara lain :
1. Lokasi penjualan dimana terletak dikawasan yang ramai akan lalu lintas, sehingga memungkinkan kontaminasi melalui udara yang mengandung debu

2. Adanya kontaminasi karena kurangnya menjaga kebersihan tempat penjualan

3. Adanya kontaminasi karena kurangnya memperhatikan kebersihan dari penjual maupun alat, wadah yang digunakan serta lama penyimpanan Tahu putih tersebut.

\section{KESIMPULAN DAN SARAN}

\section{Kesimpulan}

1. Jumlah koloni bakteri pada sampel (I) Pagi adalah $121 \times 10^{6}$

2. Jumlah koloni bakteri pada sampel (II) Siang adalah $138 \times 10^{6}$

3. Jumlah koloni bakteri pada sampel (III) Sore adalah $2.14 \times 10^{6}$

\section{Saran}

1. Diharapkan kepada setiap produsen atau penjual Tahu putih agar lebih memperhatikan kualitas dari Tahu putih tersebut.

2. Sebaiknya dilakukan uji mikrobiologis lanjutan untuk mengetahui kualitas mikrobiologis secara menyeluruh terutama bakteri patogen dan biakan bakteri lainnya.

\section{DAFTAR PUSTAKA}

Anonim, 1998, Kandungan Gizi Tahu, Majalah Sarinah vol.201, Jakarta. 
Anonim. 2000. Metode Analisis PPOMN Mikrobiologi.

Jakarta: Universitas Indonesia.

Buckle, K. A, Edwards, R.A, Fleet, G. H, Wootton, M. 1985. Ilmu Pangan.

Jakarta: Universitas Indonesia Press.

Irianto, Koes. 2006. Mikrobiologi Menguak Dunia Mikroorganisme Jilid 1.

Bandung: Yrama Widya.

Supriatna. Dadang. 2005. Membuat Tahu Sumedang. Jakarta: Penebar

Swadaya.

Wibowo, Pandu. 2003. Analisis Kadar Formalin Dalam Tahu Putih Yang Beredar Di Pasar Tradisional Kota Pontianak Dengan Menggunakan Spektofotometer UV-Sinar Tampak. Pontianak: Yayasan Rumah Sakit Islam Akademi Farmasi Pontianak.
Winarto, F.G, Kimia Pangan dan Gizi, PT. Gramedia, Jakarta. 